\title{
Changes in Free and Membrane-bound Ribosomes during the Vegetative Growth of Neurospora crassa
}

\author{
By K. D. GRINWICH AND J. R. TREVITHICK \\ Department of Biochemistry, University of Western Ontario, \\ London, Ontario, Canada
}

(Received 31 October 1972; revised 26 June 1973)

SUMMARY

Free and membrane-bound ribosomes were isolated from wild-type Neurospora crassa containing the genetic background Em 5297a at 6, I 2, I8, 24, 36, 48 and $72 \mathrm{~h}$ of growth. Log phase began at $8 \mathrm{~h}$ and continued to the end of $24 \mathrm{~h}$, the beginning of the stationary phase. The ratio of free to membrane-bound ribosomes remained relatively constant during log phase. During stationary phase, the ratio of free to bound ribosomes rose sharply because of a decrease in the concentration of bound ribosomes.

Free ribosomes are generally assumed to synthesize intracellular proteins, whereas bound ribosomes synthesize proteins intended for secretion. These changes in membrane-bound ribosomes can be correlated with the specific activity of wallbound invertase (an intracellular enzyme) of the same strain of Neurospora. We suggest that this decrease in membrane-bound ribosomes during stationary phase is of physiological significance and occurs because of a decreasing synthesis of secreted proteins.

\section{INTRODUCTION}

Ribosomes are present in most organisms in at least two major forms: bound to the endoplasmic reticulum, or free in the cytoplasm (Palade \& Siekevitz, I960). To date, many enzymes have been found to be preferentially synthesized on one type of ribosome. Free ribosomes in the rat liver synthesize intracellular soluble proteins, whereas bound ribosomes synthesize serum proteins and those intended for secretion into the extracellular space (Hicks, Drysdale \& Munro, I969; Redman, 1968). In rat liver, arginase (Tanaka \& Ogata, I97I) is preferentially synthesized on free polysomes whereas albumin is synthesized on membrane-bound polysomes (Takagi \& Ogata, I968).

The present work is an attempt to quantify changes in the free and membrane-bound ribosomes during the vegetative growth of Neurospora crassa, an Ascomycete. No study of free and bound ribosomes in a mould has as yet been reported, although the specific activity of invertase, an exoenzyme of Neurospora, varies during the life cycle (Chang \& Trevithick, 1972).

\section{METHODS}

Organism. Conidia of the wild-type Neurospora crassa containing the genetic background, Em 5297 a, obtained from the collection of R. L. Metzenberg, University of Wisconsin, Madison, Wisconsin, U.S.A., were collected from an agar-plate culture maintained in a basal growth medium (Beadle \& Tatum, 1945) with $\mathrm{I} \cdot 5 \%$ sucrose as a carbon source. The conidia were harvested by a vacuum technique, suspended in $20 \mathrm{ml}$ of distilled water, filtered through a pad of glass wool, and centrifuged at $650 \mathrm{~g}$ for $5 \mathrm{~min}$. An amount 
equivalent to $0.1 \mathrm{ml}$ of packed conidia was inoculated into a 21 flask containing $650 \mathrm{ml}$ of Fries basal growth medium supplemented with $\mathrm{I} \cdot 5 \%$ sucrose. The culture was grown from 6 to $72 \mathrm{~h}$ at $30{ }^{\circ} \mathrm{C}$ in a gyratory shaker bath at $150 \mathrm{rev}$./min (New Brunswick Scientific Co., New Brunswick, New Jersey, U.S.A.). The mycelia were harvested by filtration on a glass-fibre filter and suspended in $20 \mathrm{ml}$ of Medium A of Falvey \& Staehelin (1970), containing $10 \%(\mathrm{w} / \mathrm{v})$ sorbitol as an osmotic support.

Rupture of the mycelia. The harvested mycelia were subjected to ultrasonic disruption (Branson Soni Power Sr.25 at maximum output for 3 to $5 \mathrm{~s}$ ) and homogenized with 20 strokes of a Ten Broeck homogenizer. As an alternative method, the mycelia were ground in an equal volume of acid-washed sea sand. Both types of homogenates were centrifuged at $\mathrm{I} 3500 \mathrm{~g}$ for $\mathrm{I} 5 \mathrm{~min}$ in a Sorvall $\mathrm{RC}-2 \mathrm{~B}$ centrifuge (SS34 rotor) (Sorvall Inc., Norwalk, Connecticut, U.S.A.).

Preparation of free and bound ribosomes. The method of Blobel \& Potter (1967a) was modified as follows in our laboratory. The post-mitochondrial supernatant was layered over a discontinuous gradient of $2.5 \mathrm{ml}$ of $3.76 \mathrm{M}$-sorbitol, and $2.5 \mathrm{ml}$ of $2.44 \mathrm{M}$-sorbitol, and centrifuged in a Beckman L2-65B ultracentrifuge (Beckman Instruments Inc., Palo Alto, California, U.S.A.) for $\mathrm{r} 5 \mathrm{~h}$ at $\mathrm{I} 95000 \mathrm{~g}(40000 \mathrm{rev} . / \mathrm{min})$ in an $\mathrm{SW} 40$ rotor (Beckman Instruments). At equilibrium at $5 \mathrm{~h}$, the bound ribosomes banded throughout the $2.44 \mathrm{M}$ layer, and the free ribosomes collected as a pellet at the bottom of the tube. The membranebound ribosomes were resuspended in three times their volume in Medium A and recentrifuged in an SW 40 rotor at $106000 \mathrm{~g}(29000 \mathrm{rev} . / \mathrm{min})$ for $35 \mathrm{~min}$. The ribosomal pellet was homogenized, suspended in buffer and centrifuged in a Beckman Ti 50 rotor at $\mathrm{I} 65000 \mathrm{~g}$ for $2 \mathrm{~h}(50000 \mathrm{rev} . / \mathrm{min})$. The pellets were stored frozen at $-20{ }^{\circ} \mathrm{C}$ until used.

Analytical methods. RNA was measured by a modified Mejbaum method (Merchant, Kahn \& Murphy, 1964) using yeast RNA as a standard, or by the method of Fleck and Munro (Williams \& Rabin, I969). For protein determination, samples were hydrolysed in $5 \%$ trichloroacetic acid (Schneider, I 957) and assayed by the biuret method (Layne, 1957).

DNA was measured by the method of Burton (1956) with calf-thymus DNA as a standard. Phospholipid phosphorus was assayed by the method of Lindberg \& Ernster (1956) after Folch extraction (chloroform:methanol, 2:I) and digestion (Denton \& Randle, 1967).

NADPH cytochrome $c$ reductase (EC.I.6.2.3) activity was measured according to the method outlined by Sottocasa, Kuylenstierna, Ernster \& Bergstrand (1967). Dry weights were obtained by drying samples in a vacuum oven at $60^{\circ} \mathrm{C}$ for 30 h over $\mathrm{NaOH}$ and $\mathrm{CaSO}_{4}$.

\section{RESULTS}

Criteria of purity. Ribosomes were assayed for purity by RNA, DNA, protein, and phospholipid phosphorus content and examined by electron microscopy (Table I). Free ribosomes have been reported to contain no phospholipid (Spirin \& Gavrilova, 1968). As is illustrated in Table I, free ribosomes prepared by our modification of the method of Blobel \& Potter $(1967 a, b)$ contained about $6 \%$ of the phospholipid associated with bound ribosomes. The protein content $(5 \mathrm{I} \cdot 4 \pm 4 \cdot 2 \%$ ) is consistent with values reported by Storck (1963) for ribosomes of Neurospora crassa. The RNA/protein ratio compares favourably with the generally accepted value of I for pure ribosomes (Spirin \& Gavrilova, 1968). The membrane-bound fraction contained $14.3 \pm \mathrm{I} \cdot 8 \%$ RNA and had an RNA/protein ratio of 0.17 . DNA content was always less than $\mathrm{I} \%$, indicating that no chromatin was present in the fractions.

Disruption of the mycelia and recovery. The period of growth chosen covered the lag, 
Table I. Phospholipid content, percentage of $R N A$, percentage protein content, and $R N A$ /protein ratio of free and bound ribosomes

Membrane-bound ribosomes were not detached from the membrane. All samples were assayed in duplicate. In all groups, $n=3$. S.E. $=$ standard error.

\begin{tabular}{|c|c|c|c|c|}
\hline & $\begin{array}{c}\text { Phospholipid } \\
\mu \mathrm{mol} \text { P/mg RNA }\end{array}$ & $\begin{array}{c}\text { Percentage } \\
\text { RNA } \\
\pm \text { S.E. }\end{array}$ & $\begin{array}{l}\text { Percentage } \\
\text { protein } \\
\pm \text { S.E. }\end{array}$ & $\begin{array}{l}\text { RNA/protein } \\
\text { ratio }\end{array}$ \\
\hline & $0.015 \pm 0.008$ & $48 \cdot 5 \pm 3 \cdot 8$ & $5 I \cdot 4 \pm 4 \cdot 2$ & $0.95 \pm 0.12$ \\
\hline Bound ribosomes & $0.20 \pm 0.01$ & $\mathrm{I} 4 \cdot 3 \pm \mathrm{I} \cdot 8$ & $85 \cdot 8 \pm 1 \cdot 8$ & $0.17 \pm 0.03$ \\
\hline
\end{tabular}

Table 2. Recovery of RNA and DNA following homogenization of the mycelium

\begin{tabular}{|c|c|c|c|c|}
\hline RNA & $\begin{array}{c}\text { Time } \\
\text { (h) }\end{array}$ & $\begin{array}{c}\mathrm{Mg} / \text { flask } \\
\text { (total) }\end{array}$ & $\begin{array}{c}\mathrm{Mg} / \text { flask } \\
\text { (700 } \mathrm{g} \\
\text { supernatant) }\end{array}$ & $\begin{array}{l}\text { Percentage } \\
\text { recovery* }\end{array}$ \\
\hline Expt I & $\begin{array}{r}6 \\
18 \\
36 \\
48 \\
72\end{array}$ & $\begin{array}{l}14 \\
80 \cdot 8 \\
63 \cdot 8 \\
62 \cdot 1 \\
45 \cdot 9\end{array}$ & $\begin{array}{r}5 \cdot 4 \\
26 \cdot 4 \\
37 \cdot 6 \\
30 \cdot 8 \\
8 \cdot 0\end{array}$ & $\begin{array}{l}38 \cdot 8 \\
32 \cdot 7 \\
58 \cdot 9 \\
49 \cdot 6 \\
17 \cdot 4\end{array}$ \\
\hline Expt 2 & $\begin{array}{r}6 \\
36 \\
48 \\
72\end{array}$ & $\begin{array}{l}3 \cdot 0 \\
14.4 \\
13 \cdot 4 \\
10\end{array}$ & $\begin{array}{l}1 \cdot 3 \\
7 \cdot 2 \\
6 \cdot 9 \\
1 \cdot 8\end{array}$ & $\begin{array}{l}43 \cdot 7 \\
49 \cdot 8 \\
5 \mathrm{I} \cdot 2 \\
\mathrm{I} 7 \cdot 6\end{array}$ \\
\hline DNA & $\begin{array}{r}6 \\
12 \\
18 \\
36 \\
48 \\
72\end{array}$ & $\begin{array}{l}0 \cdot 65 \\
3 \cdot 36 \\
4 \cdot 8 \\
6 \cdot 6 \\
6 \cdot 8 \\
7 \cdot 4\end{array}$ & $\begin{array}{l}0 \cdot 27 \\
I \cdot 27 \\
2 \cdot 10 \\
2 \cdot 47 \\
2 \cdot 10 \\
2 \cdot 5\end{array}$ & $\begin{array}{l}4 I \cdot 5 \\
37 \cdot 8 \\
42 \cdot 3 \\
37 \cdot 4 \\
3 I \cdot I \\
34 \cdot I\end{array}$ \\
\hline
\end{tabular}

$*$ For RNA, $\bar{x}=38 \cdot 0$ and S.E. $= \pm 5 \cdot 0$; for DNA, $\bar{x}=38 \cdot 0$ and S.E. $= \pm 2 \cdot 0$.

$\log$, and stationary phase of growth (Fig. 1). Samples were taken at 6, I2, I8, 24, 36, 48 and $72 \mathrm{~h}$ of growth. Log phase began at $8 \mathrm{~h}$ and continued through $24 \mathrm{~h}$, the beginning of stationary phase. Samples were disrupted as previously described either by sonic oscillation treatment followed by homogenization or by grinding in acid-washed sea sand. Although the sonic treatment appeared to disrupt an insignificant number of mycelia, as determined by phase-contrast microscopy $(40 \times)$, it appeared to increase the percentage of mycelia broken during the subsequent homogenization. The relative amount of mycelia broken was $38 \pm 2 \%$ $(n=5)$ of the total sample as measured by DNA content, and $38 \pm 5 \%(n=7)$ as measured by RNA content (Table 2). As an average of all determinations during the different time periods studied (from 6 to $72 \mathrm{~h}$ of growth), the recovery of ribosomes from the postmitochondrial supernatant was $9 \mathrm{I} \pm \mathrm{I} 5 \%(n=9)$ as measured by RNA content (Table 3$)$.

Changes in the free and membrane-bound ribosomal fractions. Changes occurred in the ratio of free to bound ribosomes in Neurospora crassa during vegetative growth (Fig. I). The ratio for the homogenized samples remained relatively constant until the end of log phase and then increased steadily during stationary phase. Sand-ground samples exhibited the same trend. NADPH cytochrome $c$ reductase activity, a microsomal marker, was measured to determine the amount of endoplasmic reticulum that was associated with the mitochondrial pellet. The activity of this enzyme in the mitochondrial fraction was always 
Table 3. The purity of homogenate fractions: the relative recoveries of $R N A$ and of NADPHcytochrome $c$ reductase in the ribosomal fraction and post-mitochondrial supernatant

RNA and cytochrome $c$ reductase activity were estimated as described in Methods.

The relative recovery of RNA in the ribosomal

fraction and post-mitochondrial supernatant

Growth period

RNA recovered in the ribo-

(h) somal fractions* $(\%)$

$\begin{array}{rcc}6 & 139.9 & - \\ 12 & - & - \\ 18 & 94 \cdot 7 & - \\ 36 & 51 \cdot 0 & - \\ 48 & 77 \cdot 1 & - \\ 72 & 68.7 & 115.4\end{array}$

The relative recovery of NADPH-cytochrome $c$ reductase in the mitochondrial fraction and the post-mitochondrial supernatant

$\begin{array}{ccccc}\begin{array}{c}\text { Time } \\ \text { (h) }\end{array} & \begin{array}{c}\text { Whole cell } \\ \text { homogenate } \\ \text { (units/flask) }\end{array} & \begin{array}{c}\text { I3500g } \\ \text { pellet }\end{array} & \begin{array}{c}\text { I3500 g } \\ \text { supernatant }\end{array} & \begin{array}{c}\text { Percentage of } \\ \text { enzyme in pellet }\end{array} \\ \text { I8 } & 35000 & 2000 & 30000 & 5 \cdot 7 \\ 24 & 25000 & 1000 & 25000 & 4 \cdot 0 \\ 42 & 25000 & 1780 & 21500 & 7 \cdot 1 \\ & & & & \text { (mean 5.6.0.9) }\end{array}$

* The total amount of RNA in both free and bound ribosomal fractions was obtained by adding the amounts in the individual fractions, and is expressed as a percentage of the amount in the post-mitochondrial ( 13500 g) supernatant. $\bar{x}=9$ I ० O S.E. $= \pm 15 \circ$.

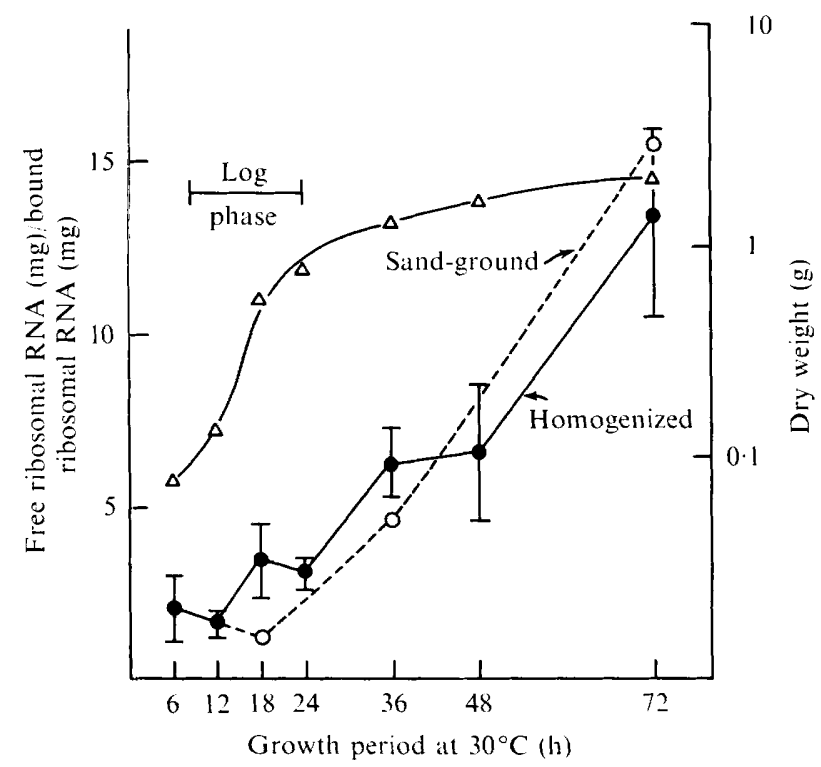

Fig. I. Ratio of free to bound ribosomes during vegetative growth of Neurospora crassa. The ratio was obtained by calculating the total concentration of free ribosomal RNA per culture: total concentration of bound ribosomal RNA per culture. $\bullet$, Homogenized samples; $O$, sand-ground samples; $\triangle$, growth curve. 


\section{Table 4. Relative RNA contents of free and membrane-bound ribosome preparations}

The total free and membrane-bound RNA content per culture was normalized to $100 \%$ at $24 \mathrm{~h}$, the end of log growth. The RNA content per fraction per culture after different periods of growth was calculated as a percentage of the $24 \mathrm{~h}$ content; in four separate experiments the $24 \mathrm{~h}$ value used for free ribosomes, followed by the value for bound ribosomes, were (mg RNA/culture): I $8 \cdot 3,5 \cdot 7 ; 17 \cdot 8,5 \cdot 0 ; 5 \cdot 8,3 \cdot 5$; and $5 \cdot 5,2 \cdot 2$. RNA was assayed according to the orcinol method (Merchant et al. 1964 ) or by reading absorbance at $260 \mathrm{~nm}$ (Williams \& Rabin, 1969).

\begin{tabular}{|c|c|c|}
\hline $\begin{array}{l}\text { Growth period } \\
\text { (h) }\end{array}$ & $\begin{array}{c}\text { Free ribosomes } \\
\text { mean } \pm \text { S.E. }(n)\end{array}$ & $\begin{array}{c}\text { Bound ribosomes } \\
\text { mean } \pm \text { s.E. }(n)\end{array}$ \\
\hline 6 & $I \cdot 7 \pm 0.4$ & $3 \cdot 8 \pm 2 \cdot 1 \quad$ (2) \\
\hline I 2 & $23 \cdot 5 \pm 5 \cdot 3 \quad(3)$ & $46 \cdot 2 \pm 10 \cdot 9(3)$ \\
\hline 18 & $64 \cdot 5 \pm 11 \cdot 9(3)$ & $55.2 \pm 6.6$ \\
\hline 24 & 100 & 100 \\
\hline 36 & $100 \cdot 5 \pm 9.4$ & $92 \cdot 8 \pm 32 \cdot 4(3)$ \\
\hline 48 & $82 \cdot 7 \pm 21 \cdot 7(4)$ & $43.9 \pm 16.9(4)$ \\
\hline 72 & $66 \cdot I \pm I 8 \cdot 8(3)$ & $19.4 \pm 8.6 \quad(3)$ \\
\hline
\end{tabular}

less than I0 \% $(8 \cdot 0 \pm \mathrm{I} \cdot 5 \%)$ of the total cellular activity throughout the time course in this study. This, together with the fact that sand-ground samples exhibited the same trend, indicates that the change in ratio is unlikely to be the result of different amounts of bound endoplasmic reticulum being sedimented in the mitochondrial fraction. Rolleston \& Mak (I972) have indicated that the low ionic strength of the buffer used may cause artifactual binding of ribosomes to smooth membranes in rat liver. In preliminary experiments, we found that there was no significant difference in the ratio of free to bound ribosomes when the ionic strength of the buffer was increased tenfold. For this reason, all experiments were done at the original concentration used by Blobel \& Potter (1967a).

The change in the ratio during stationary phase could have been the result of an increased number of free ribosomes or a decreased number of bound ribosomes. Table 4 shows the RNA content of the free and bound ribosomal fraction per culture expressed as a percentage of the total RNA content of each fraction, respectively, at $24 \mathrm{~h}$, the end of log phase. The RNA content per culture of both the free and membrane-bound ribosome fraction increased until early stationary phase, and this increase was similar for both types of ribosomes. However, after 36 hours the RNA content per culture of the membrane-bound ribosome fraction decreased at a much greater rate than that of the free-ribosome fraction, indicating a decrease in the concentration of membrane-bound ribosomes relative to free ribosomes. The sharp increase in the ratio would therefore seem to have been the result of a relatively greater decrease in the concentration of bound ribosomes as compared to free ribosomes during stationary phase.

\section{DISCUSSION}

Changes in free and membrane-bound ribosomes have been studied in several different systems. Hayashi \& Kazmierowski (1972) have shown that there are distinct changes in free and membrane-bound ribosomes in the rat liver during starvation. After $4 \mathrm{~h}$ there is a marked drop in free ribosomes, whereas after $48 \mathrm{~h}$ the bound ribosomal fraction shows a marked depression in metabolic activity. Gare \& Setterfield (1972) have found that early in the ageing of artichoke tuber slices, the number of membrane-bound ribosomes increased sharply.

Although it is not possible to ascribe a physiological role to the decrease in membranebound ribosomes found in Neurospora during stationary phase, because it is not yet known 
whether all the ribosomes found during the log phase are active in protein synthesis, the following hypothesis is put forth. Our data are consistent with the generally accepted view of the role of free and membrane-bound ribosomes in the preferential synthesis of soluble and secretory proteins respectively. We suggest that the changes in the relative amounts of bound ribosomes is related to a decreased production of secreted proteins. During log phase, protein synthesis occurs at a greater rate than during stationary phase. As a corollary, enzymes must be secreted at a greater rate during log phase to permit the mould to obtain the nutrients necessary for growth from the medium. Drucker (1972) found that the extracellular (present in the growth medium) proteases increased parallel with growth throughout log phase and that this increase in concentration could be blocked by cycloheximide, but made no studies of stationary phase cultures. Chang \& Trevithick (1972) found that the specific activity of the wall-bound invertase of Neurospora crassa increases during log phase, and is lower in conidia and during stationary phase. Klis \& Hak (1972) have correlated wall-bound invertase activity with de novo protein synthesis in Convolvulus callus. Thus the decrease in invertase secretion during stationary phase is likely to be due to a decreased synthesis of invertase. This decreased synthesis of invertase is consistent with the decrease in the concentration of membrane-bound ribosomes.

The authors thank Dr F. Rolleston for helpful discussions during the course of this work, and Dr W. C. McMurray, L. Mitchell, and L. Rogers for assistance with the electron micrographs. A grant from the MRC of Canada is gratefully acknowledged.

\section{REFERENCES}

Beadle, G. W. \& TAtum, E. L. (I945). Neurospora. II. Methods of producing and detecting mutants with nutritional requirements. American Journal of Botany 32, 678-686.

Blobel, G. \& PotTer, V. R. (I967a). Studies on free and membrane-bound ribosomes in rat liver. 1. Distribution as related to total cellular RNA. Journal of Molecular Biology 26, 279-292.

Blobel, G. \& Potter, V. R. (I967 b). Ribosomes in rat liver: An estimation of the percentage of free and membrane-bound ribosomes interacting with messenger RNA in vivo. Journal of Molecular Biology $\mathbf{2 8}$, $539-542$.

Burton, K. (1956). A study of the conditions and mechanisms of the diphenylamine reaction for the colorimetric estimation of DNA. Biochemical Journal 62, 315-323.

Chang, P. L. Y. \& Trevithick, J. R. (1972). Distribution of wall-bound invertase during the asexual life cycle of Neurospora crassa. Journal of General Microbiology 7o, 23-29.

Denton, R. M. \& RandLe, P. J. (1967). Concentration of glycerides and phospholipid in rat heart and gastrocnemius muscle. Biochemical Journal ro4, 416-422.

DRUCKER, H. (1972). Regulation of exocellular proteases in Neurospora crassa: Induction and repression of enzyme synthesis. Journal of Bacteriology Imo, 104I-1049.

Falvey, A. K. \& Staehelin, T. (1970). Structure and function of mammalian ribosomes. I. Isolation and characterization of active liver ribosomal subunits. Journal of Molecular Biology 53, I-I9.

Gare, R. \& Setterfield, G. (1972). Changes in ribosomes of artichoke tuber slices during 'aging'. Canadian Society of Plant Physiologists, Eastern Section Meeting, p. 5.

HAYASH, T. T. \& KAZMIERowsKi, D. (I972). Changes in free and membrane-bound ribosomes in the rat liver with starvation. Biochemistry II, 2371-2378.

Hicks, S. J., Drysdale, J. W. \& Munro, H. N. (1969). Preferential synthesis of ferritin and albumin by different populations of liver polysomes. Science, New York 164, 584-585.

KLIS, R. M. \& HAK, A. (1972). Wall-bound invertase activity in Convolvulus callus: Increase after subculturing, and paradoxical effects of actinomycin D, cycloheximide, and thienylalanine. Physiologia plantarum 26, 364-368.

LAYNE, E. (1957). Spectrophotometric and turbidometric methods for measuring protein. In Methods in Enzymology, vol. 5, pp. 450-45I. Edited by S. Colowick and N. Kaplan. New York: Academic Press. 
LINDBERG, O. \& ERNSTER, L. (I956). Determination of organic phosphorus compounds by phosphate analysis. Methods in Biochemical Analysis 3, I-19.

Merchant, D. J., Kahn, R. H. \& MURPhy, W. H. (1964). Handbook of Cell and Organ Culture, pp. I62-I 66. Minneapolis: Burgess.

Palade, G. E. \& Siekevitz, P. (1956). Liver microsomes: An integrated morphological and biochemical study. Journal of Biophysical and Biochemical Cytology 2, 17I-198.

REDMAN, C. M. (I968). The synthesis of serum proteins on attached rather than free ribosomes of rat liver. Biochemical and Biophysical Research Communications 31, 845-850.

Rolleston, F. S. \& MAK, D. (1973). The binding of polyribosomes to smooth and rough endoplasmicreticulum membranes. Biochemical Journal I3I, 85I-853.

SCHNEIDER, W. C. (I957). Determination of nucleic acids in tissues by pentose analysis. In Methods in Enzymology, vol. 3, pp. 680-682. Edited by S. P. Colowick and N. O. Kaplan. New York: Academic Press.

Sottocasa, G. L., Kuylenstierna, G., Ernster, L. \& Bergstrand, A. (i967). An electron transport system associated with the outer membrane of liver mitochondria. Journal of Cell Biology 32, 415-438.

Spirin, A. S. \& Gavrilova, L. L. (I968). The Ribosome. New York: Springer-Verlag.

STORCK, R. (1963). Characterization of ribosomes from Neurospora crassa. Biophysics Journal 3, I-9.

TAKAGI, M. \& OGATA, K. (I968). Direct evidence for albumin synthesis by membrane-bound polysomes in rat liver. Biochemical and Biophysical Research Communications 33, 55-60.

TANAKa, T. \& OGATA, K. (1971). Preferential synthesis of arginase by free polysomes from rat liver. Journal of Biochemistry 70, 693-697.

Williams, D. J. \& RABIN, B. R. (1969). The effects of Aflatoxin Bi and steroid hormones on polysome binding to microsomal membranes as measured by activity of an enzyme catalysing disulphide interchange. Federation of European Biochemical Societies' Letters 4, 103-107. 